\title{
The Graduates' Employability Challenges in Tanzania: A Philosophical Response from Martin Buber's Concept of Education as a Dialogue
}

\author{
Longino Rutagwelera Kamuhabwa ${ }^{\text {a }}$
}

Received: 17 July 2019• Accepted: 29 September 2019

\begin{abstract}
University and College graduates in Tanzania and elsewhere are claimed not only unemployed but also unemployable. With a philosophical-analytical method, this paper seeks to tackle the problem as how to raise the employability level of such graduates in Tanzania and elsewhere. Inspired by Martin Buber's philosophy of education as dialogue, we discuss the learner-centeredness in teaching and learning as a contributory approach to resolving the challenge. We explore the intrinsic dialogical and creative instincts of the learner and the way to exploit them in order to make the learner both knowledgeable and employable. We expose findings of the effectiveness of mainstreaming a diversity of interactive dialogue into all decision making forums and processes. We recommend a dialogue of commonality of interests and efforts of both the labour industry and the academia in solving the graduates' employability challenges rather exchanging blames and defensiveness.
\end{abstract}

Key-Words: Employability, Intersubjectivity, Dialogue, Philosophy of Education, Communion Instinct.

\section{Introduction}

In the $21^{\text {st }}$ century Tanzania and other countries experience a wide range of complaints that a good number of college and university graduates do not deliver to the optimal demands of the labour market (Mwita, 2008: 263).

\footnotetext{
${ }^{a}$ Songea Catholic Institute of Technical Education (Tanzania). Correspondence: Longino Rutagwelera Kamuhabwa.Songea Catholic Institute of Technical Education. P. O. Box 466. Songea, Tanzania. rutagwelera2000@gmail.com
} 
Such graduates are claimed questionable both for employability and for selfemployment. This dissatisfaction provokes our problem as to how education should be conceived and approached in order to make the educated ones responsive to the contemporary needs and appeals of the society.

In approaching this problem first we expose some concrete situations of graduate employability problems in Tanzania. Secondly, we descriptively and critically take the educational philosophy of Martin Buber as our theoretical base to tackle the problem. We apply his theory to the contemporary educational set up in order to make it produce graduates who are both creative and interactive [In this paper creativity and interactivity are used to correspond with Martin Buber's concepts of the originator instinct and the communicative instinct respectively]. These are the two qualities which in this paper we expound as indispensable for the graduates to be employable in the sense of having knowledge and skills for them to deliver as responsive job creators and responsive employees.

\section{Scenarios of Graduate Employability Challenges in Tanzania}

A number of countries worldwide are facing unemployment of the youth at large but in particular of the university and college graduates. In some countries there is a lot of investment in tertiary education but still the outputs remain not only unemployed but also unemployable. Tanzania in particular is facing the same problem. Appealing to the studies conducted, there are some findings of which the job industry complains against the academia that the products of the latter do not satisfy the current expectations and the demands of the labour market (Mbise, 2016: 2). In short, graduates are accused of lacking job readiness qualities.

Researchers have revealed a number of factors which contribute to such deficiencies as we shall expose. In the meantime, we provoke a discussion pertaining to the relationship between the core roles of universities and colleges on one hand and employability challenges of the college and university graduates on the other. We bring on board Martin Buber's philosophy of education exploring its tenets to see how they can help resolve the graduates' employability challenges that Tanzania and other countries are facing.

Researches conducted in Tanzania on the graduate employability challenges have come out with a variety of findings. Emmanuel J. Munishi with a focus on graduates from Institutions of Technical and Vocational Education and Training maintains that graduates from such institutions in Tanzania lack employability skills due to the variety of factors (Munishi, 2016:1-2). For him such deficiency is among others, due to poor foundation at the lower levels of learning. Such poor foundation is a result of lacking competent teachers, lack of adequate number of qualified teachers, lack of 
proper remuneration and motivation of teachers, and lack of adequate learning space and facilities (Munishi, 2016:6-7). Other factors include poor educational policy (Munishi, 2016:11) and disoriented emphasis in learning which, for him is knowledge-based instead of being competence-based.

In our analysis we take these factors as extrinsic to the learners but with intrinsic effects on the learners. It is only the last factor which touches the deficient method used in the process of educating and training. If all these pitfalls were to be sorted out, would it follow by logical necessity that the respective graduates would be employable? What would be the result if there were an adequate number of competent and qualified well motivated, amicably remunerated instructors backed by good policies, working in an environment rich of space and facilities for teaching and learning but working on wrong matter in the sense that they instruct students who are intrinsically incapable to assimilate the curriculum content? Again, what is to determine the other: are the job market needs to determine the content, the method and objectives of the academic endeavours, or rather conversely the academia has to shape and give direction to the job market needs? It is against such questions that in this paper we make recourse to Martin Buber's philosophy of education in which he takes the intrinsic nature of the learner as the determinant factor for the content and method of education. This means, it is the learner-centered approach, which takes the intrinsic nature of the learner as a focus of teaching and learning which renders the learner properly knowledgeable, adequately skilled and thus employable [the learner-centred approach explores the learner in his/her talents, attitudes, potentials, background, interests, etc.].

Another study relevant to this paper was carried out by James Mbalamwezi in 2015. According to this study factors for youth employability challenges are poor education quality, improper education system which gives no room to training in entrepreneurial skills, improper employers' overcapitalization on work experience which makes adults and thus the more experienced at work to be preferable to the youth as non experienced job seekers (Mbalamwezi, 2015: 72).

Analyzing the findings of Mbalamwezi, we deem some factors for unemployment as being closely related to the factors for unemployability of the youth. Although his study is focused on the youth at large, his findings still suit our study which focuses on the graduates from institutions of tertiary education. As we shall expose later, training in entrepreneurial skills as Mbalamwezi recommends touches and activates the learner's instinct to be active and creative - an important part of the qualities which employers expect from the job seekers. He also recommends formation or rather transformation of the graduates' mindset from being employed to selfemployment. As this touches the inner self of the learner it is an approach which creates a spirit of dynamism which is beneficial not only to the learner 
but also to the employer. We deem the attitude of dynamism as an added quality, and a soft skill for one to work efficiently and effectively in the dynamic job market. Teaching and training which help change the mindset and attitude therefore, raise the employability level, and thus make the teaching institutions responsive and their graduates marketable.

The study which Christina Jerome Shuma carried out at the University of Dodoma and at Saint John's University of Tanzania (Shuma, 2017) reveals that the employability challenges among graduates from Institutions of Higher Learning mainly result from the lack of career guidance and counseling. In her recommendations Christina maintains that career guidance and counseling should be mainstreamed in the curriculums. It should be part of the services offered to the students. Units and clubs of career guidance and counseling have to be established, and career days have to be inserted in the institutional almanacs. Over and above, all these have to be done and superintended by competent and experienced experts in career guidance and counseling (Shuma, 2017: 94). The study commends the initiative of bettering the students' employability skills by making practical training part of the curriculum (Shuma, 2017: 95). Her findings and recommendations touch the inner self of the learner. In her view therefore, it is the proper exploitation and orientation of the inner potentialities of the learners which give them job readiness and thus make them employable.

In the year 2016 Lyata Ndyali conducted a study on the factors for the joblessness of graduates in Tanzania. Among the findings, the study reveals poor dialogue between the Institutions of Higher Learning on one hand and the job industry on the other. The lack of adequate interaction between the two parties makes the former to be left behind by the rapidly changing world of science and technology. This results into a mismatch between what the Institutions offer and stand for on one hand and what the dynamics of the changing job market expect and demand (Ndyali, 2016: 117). It is in this context Lyata Ndyali, among others urges Institutions of Higher Learning to keep on doing self-evaluation and self-transformation as he says:

...(they) should watch changes and demands of the labor market so that they could rethink, repackage, reposition and reengineer their missions, messages and methods in line with the changing requirements of the labor market and those of the local communities continue. (Ndyali, 2016: 120)

Putting this quotation in the context of our paper Lyata Ndyali recommends dynamism, flexibility and the proactive attitude for the Institutions of Higher Learning to keep pace with the ever changing world of job industry. Lyata Ndyali however, does not confine the role of the Institutions of Higher Learning to preparing graduates only for the job market. 
For him, the same institutions orient graduates also for self-reliance, for responsible good citizenship, and for selfless leadership (Ndyali, 2016: 116).

Basing ourselves on the recommendations of Lyata Ndyali, is it fair to confine ourselves on the non-employability of graduates to disqualify their respective colleges and universities? In other words, does the lack of employability skills imply the lack of qualities of a good and responsible learned citizen who can make a selfless leader? Is it just and fair to judge and discredit Institutions basing on one parameter of producing unemployable graduates without considering other outcomes which may include responsible citizenry and committed leaders? These are some of the questions which, associating them with the Tanzanian context are responded to with recourse to the Educational Philosophy of Martin Buber. If universities and colleges are fairly given their rightful place which holistically addresses the whole spectrum of social, political, economic, and cultural issues it would be inconsistent and unfair to discredit them just on the lines of non-employability of their graduates.

The study carried out by Nuru Kalufya and Lucas Mwakajinga at the Institute of Social Work in Dar es Salaam, Tanzania in 2016 highlights the blame extended to Institutions of Higher Learning for producing graduates who do not satisfy expectations of employers (Kalufya and Mwakajinga, 2016: 51, 53). The researchers associated the employability challenges with the lack of self awareness among the graduates, low level of interpersonal skills, lack of problem solving skills, low level of teamwork spirit, and lacking link between theoretical learning in class and the practical employability in the job industry (Kalufya and Mwakajinga, 2016: 64). Among others, they recommend Career Advisory Services for enhancing self awareness as an employability skill needed for responding to the demands of the job market(Kalufya and Mwakajinga, 2016: 64). They also recommend establishment of forums for career enhancement such as career events, finalists' workshops for employability and for practical initiation to the job industry. These two researchers put emphasis on soft skills rooted in the inner self of the learner. It is the attitudinal formation for instance which makes one have proper self-awareness, and awareness of what and where his/her are potentialities are, of how to relate with others in teamwork spirit, etc.

G. D. Mjema conducted a study on unemployment in Tanzania and submitted a report of the same to the International Labour Organization (ILO) in 1999. According to this study there are several factors for unemployment and employability challenges in Tanzania. Those which we deem mostly suited to our study include inadequate education system which results into lack of employability skills (Mjema, 1990: 23), and lack of forums for career advisory services (Mjema, 1990: 25). This report highlights deficiencies in the educational system which gives no space for attitude orientation and 
formation - aspects which in our view would touch the inner self of the learner.

In the report of The National Skills Development Study of June 2014 it was highlighted that $70 \%$ of the employers in Tanzania expect a high degree of soft skills from the employees who unfortunately lack them (Mbwanji, 2014: 25). Such lacking skills include communication skills, personal qualities [according to Rasul et al. (2013) the personal qualities which count as employability skills include self-confidence, self-esteem, commitment, reliability, moral uprightness, positive attitude, honesty, truthfulness, trustworthiness, sociability, etc.], problem solving skills, teamwork skills, adaptability, leadership skills, capacity to translate theoretical knowledge into practice, and time management skills (Mbwanji, 2014: 25). Again, this report shows that the level of employability depends much more on the inner formation of the learners which makes them interactive, dynamic, selfconfident, and practice-oriented.

Another study relevant to this paper was conducted by Kelvin M. Mwita in 2018. The major findings of this study which are pertinent to our paper reveal that the graduates' employability challenges are associated with the lack of adaptability, average core skills (Mwita, 2018: 267), and average subject knowledge (Mwita, 2018: 268). The general observation is that graduates from the Tanzanian Institutions of Higher Learning are average products and thus do not meet the required standards of the competitive job market. Focusing on the named general observation, in our view, efforts done by the Institutions of Higher Learning could be directed to wrong matter that is, directed to learners who intrinsically are incapable of assimilating the curriculum content. It is here we insist self awareness of the learners to be given upper hand in the whole process of learning so that one may not be blamed for what he/she cannot achieve.

\section{A Philosophical Response from Martin Buber's Philosophy of Education}

For Martin Buber, to educate a person is to empower his/her two inherent spiritual instincts: the originator instinct and the communion instinct (Cohen, 1983: 31, 37). While the former gives one power to create or to bring something into existence (Cohen, 1983: 30), the latter gives one power to recognize the world and other human beings whom he/she encounters in the world (Cohen, 1983: 31).

In this paper, we aim at exposing Martin Buber's understanding of the human person as naturally endowed with these two intrinsic powers. We aim at discussing education as a process of first and foremost enabling the learner to have a thorough knowledge of the self. Our central argument is to establish that to impart or to acquire a set of knowledge is not the aim of education but 
just a step towards its proper objective of enabling one to create and to enter into a dialogical existence (Guilherme and Morgan, 2009: 568). Creativity and dialogue are realized on levels. They begin with the self, then the other as Thou and the world in which one exists. Beginning with self-knowledge therefore, education enables one to know his/her world in which one is concretely situated. It also helps one know the other human beings as Thou whom he/she encounters in the world.

In his theory of education, Martin Buber was in favour of subjective education as opposed to objective education (Cohen, 1983: 12). While the former takes the object of learning to be within the self of the learner, the latter takes the object of learning as being outside the learner [in promoting subjective education as opposed to objective education Martin Buber encouraged a man-centred approach and thus discouraged taking events and documentaries as the centre of learning]. In favour of subjective learning, Martin Buber took self-knowledge as the primary object of all learning. It is the thorough knowledge of the self which puts the learner in a position of learning and knowing the rest.

As hinted upon in the introduction education as knowledge of the self focuses on the two instincts: the originator instinct and the communion instinct which are inherent constitutive features of the self (Cohen, 1983: 31). The originator instinct is that inner drive of knowing oneself and one's world. In the role of knowing oneself, the originator instinct also helps one discern reality on the ethics matrix of what is good against what is evil, what is right against what is wrong (Murphy, 1988: 137). The communion instinct on the other hand helps the learner enter into a dialogical encounter with the other as Thou (Cohen, 1983: 31).

According to Martin Buber however, neither of the two instincts can exist without the other (Green, 1999: 146-147). Even in matters of teaching and learning, education cannot be complete and authentic if it concentrates on one while totally excluding the other. It is against this background that in this paper each instinct is given a due treatment as follows in the subsequent subtopics.

\subsection{The originator instinct and its educational dimensions}

In his anthropology, Buber understands a human person at all stages of growth as endowed with a natural urge and inclination to give form, that is, to fabricate, to contribute to the being of what he/she encounters (Buber, 2002: 85). This natural inclination is a concrete dimension of what Buber terms the originator instinct [originator instinct is also referred to as originative instinct or instinct of origination.], which for him is neither learned nor derived from another person. This means, the originator instinct is inherently a natural component of the human essence. 


\subsubsection{Education for self-knowledge and for character formation}

In Buber's line of thought, knowledge is an integral dimension of education. It is through this dimension that one discovers the truth about himself/herself, about his/her world and about the other selves whom he/she encounters (Cohen, 1983: 37). This multidimensional discovery is not an end itself but a step towards a higher end which is empowerment to create. But do being educated and being creative have the same comprehension and the same extension? In other words, is it justifiable that every educated person is creative, and that every creative person is educated? How can one argue to defend Buber's stand in relation to speculative knowledge which by its nature is not directly creative?

In relation to these questions, we argue that for Buber knowledge is neither co-comprehensional nor co-extensional with education. Having knowledge is not the same as being educated although no one can claim to be educated without having a set of knowledge. In other words, being educated includes both in comprehension and in extension being knowledgeable. It is in this line of thought that Buber makes a difference between 'teaching a person in order to know' and 'teaching a person in order to be'. (Buber, 2002: 104). While the former makes one have or be conversant with a set of knowledge, the latter nurtures or forms one in his/her character. Quoting Buber we read:

Education worthy of the name is essentially education of character. For the genuine educator does not merely consider individual functions of his pupil, as one intending to teach him only to know... but his concern is always the person as a whole, both in his actuality ... and in his possibilities, what he can become. (Buber, 2002: 104).

With this difference, Buber does not however underestimate the role of knowledge in the whole educational enterprise. Basing on his words, we maintain that the difference between 'teaching a person in order to know' and 'teaching a person in order to be' is a difference not of nature but rather, of degree. In knowledge-oriented education students learn something, but in character-oriented education students become of this or of that quality. What is acquired as knowledge has to contribute to the formation of character. Being a component of character formation therefore, knowledge is not excluded from education, and this is the ground for the two to differ in degree, not in nature.

Buber gives a caution as to the natural tendency among students to embrace knowledge-oriented learning while shunning away from characteroriented learning (Buber, 2002: 105). For him, students are more attracted to knowledge than to character formation. Is this tendency motivated by the very nature of students or by the content of the object of education? In other words, 
why, according to Buber knowing something is more attractive than becoming of this or of that character?

In relation to this question, I would argue and maintain that an object of knowledge is not part of the knower until it is known. Character on the other hand is an integral component of every human being. While knowledgeoriented education makes one acquire something new, character-oriented education is an attempt to change what one already is. This line of thought makes us maintain that it is more attractive to have than to change, that is, it is more palatable to acquire something than to change the way of being. I also argue, being inspired by Martin Buber that, one of the first tasks of an educator is to work on this natural tendency by forming the character of preferring being (changing) to having. Knowledge which is acquired therefore, may not be taken as something for having but rather as component of character formation. In other words, knowledge is to contribute to the students' growth in character.

The whole of character education is summed up in what Martin Buber conceives of the nature and role of an educator whom he analogically portrays both as a gardener and a sculptor (Murphy, 1988: 90). The role of a gardener is to facilitate germination and growth of what is intrinsic to the seed. He/she waters and manures the soil, prunes the plant and makes weeding so that what is potential in the seed may come to actuality in the sense of sprouting. The gardener therefore, does not bring anything into the seed but facilitates its germination and growth. This is the analogical role of an educator who, for Buber is to facilitate character growth in the learner from within rather than conducting indoctrination which imports doctrines and principles from outside.

The second analogy applicable for character education is that of likening an educator with a sculptor who does the work of bringing out a beautiful shape hidden in a piece of marble (Murphy, 1988: 90). The sculptor shapes marble into a statue while being guided by two principles. The first is the beautiful shape inherent in a piece of marble, and secondly is like a blue print of that shape which a sculptor has in his/her mind (Murphy, 1988: 90). This is an analogical depiction of the nature and role of an educator that in the formation of the characters of learners, he/she works on what is inherent in the being of the learner through the instrumentally of his/her formed character.

\subsubsection{Education for empowerment to create}

For Martin Buber to create is to bring to light, to discover, to generate, to make something come into existence or to give a form to something (Cohen, 1983: 30). For him, every human person has an intrinsic creative power of giving form to himself/herself and to all that he/she encounters. It is through education that the student's creative power is enabled to effect something. As Seymour Rossel comments, for Buber “... education is an art 
of bringing the student's potential into reality through communication." (Seymour, 1998: 30). In Buber's mind however, a teacher does not create a student but he/she rather molds what a student is as a potential. It is against this background he maintains, "The child is a reality; education must become a reality." (Buber, 2002: 84 ). To conceive a student as a reality is to recognize what he/she is as a subject of encounter and of formation rather than emptiness to be filled with a set of doctrine (Flanagan, 2006: 163-164). As a reality therefore, a student has to be taken in his/her uniqueness of being and uniqueness of need rather than being taken as an object of a generalized instruction and intellectual feeding (Yadav, 2002: 55).

With this understanding therefore, education is to be taken as a mechanism of molding students in their potentials rather than addressing external forces such as the market needs. With this approach, each graduate as a prospective employee is to be employed and gauged according to his/her molded and oriented talents rather than being branded as unemployable basing merely on not meeting the needs of the market. An approach which is more realistic in this regard would be seeking a dialogical relationship between the students' talents and the labour market needs. This may be realized by molding and orienting the students' talents and dispositions making them responsive to the labour market needs.

\subsubsection{Education for self-creation}

Conceived as a reality by the educator, a student first and foremost through education has to know what he/she actually is and what his/her potentiality carries. Education therefore facilitates self-knowledge - the knowledge which among others encompasses awareness of having the creative potential. This knowledge includes as well knowledge of the self as an $I$ and a Thou to others and at the same time acknowledging others as Thou, that is, as subjects of encounter. We take self-knowledge as a starting point of self-creation as it makes one to know, and motivates him/her to be what he/she is to be, that is, to be a person of creativity and of encounter. In a word, self-knowledge has a formative effect on the self, and thus puts one in a position to have a creative effect on the quality of his/her personality in general and on his/her character in particular.

A creative instinct directed on the self makes a contribution towards self-molding. This involves adaptation, flexibility, internal disposition - all contributing to making oneself more suited to a given situation. Applying this understanding to the graduates' employability challenges, each graduate has a role to play for him/her to be employable. A student has to be attitudinally tuned to create himself/herself in the sense of having readiness and flexibility to adapt and to adjust himself/herself to suit and meet the market demands. This understanding shows the role to be played by the graduates themselves in 
the whole process of making themselves employable rather than pushing the whole burden to their respective universities and colleges.

\subsection{The communion instinct: buber's philosophy of dialogue}

A communion instinct is a second instinct which according to Martin Buber is another inherent component of the human self. It is an instinct upon which the dialogical nature of human beings hinges. Martin Buber describes this instinct as:

... the longing for the world to become present to us as a person, which goes out to us as we to it, which chooses and recognizes us as we do it, which is confirmed in us as we in it. (Buber, 2002: 104).

It is by this instinct that a human person recognizes, personifies and opens up to the world around him/her as a subject of encounter and interaction for mutual confirmation and enrichment (Cohen, 1983: 31). It is an instinct of dialogue which takes life as essentially and existentially interactive and communal. We now bring on board this concept of the communion instinct to see the way it helps cultivate a dialogical relationship in the whole enterprises of higher education on one hand and the labour industry on the other as a move to sort out the graduates' employability challenges in Tanzania and elsewhere. In other words, we advance a study on this instinct aiming at showing how communication, dialogue, and interaction skills are vital components required of graduates for them to meet employability demands of the labour market.

\subsubsection{Martin Buber on education and dialogue}

For Martin Buber education at all levels is essentially dialogical (Friedman, 1956: 176). It is a process which cherishes a teacher-student mutual relationship built on mutual presence, mutual openness and mutual trust (Friedman, 1956: 176). Through education students are nurtured to cultivate $I$-Thou attitude by which they encounter others in their otherness as persons not as objects, as subjects of love, of care and of dignified service (Murphy, 1988: 71). Reciprocally, education has to prepare each student to receive dignified fulfillment from the labour market. $\mathrm{He} / \mathrm{she}$ is to be recognized by the same as thou, as a person with inherent dignity coming on board in the labour industry to reciprocate a fulfilling dignity rather than being taken as a problem-solving tool, a cost effective human machine out there to meet and satisfy demeaning utilitarian expectations of employers. All this is possible if students are equipped with dialogical skills, and if the labour market takes dialogue as quality not only of employees but of employers as well. 
Bringing this philosophy to the context of this paper, we stretch the dialogical relationship from a teacher and students to include a dialogue between labour industry and Institutions of Higher Learning. The latter will include interaction at different levels: between the employers and the academia, between employers and students as prospective graduate employees, between employers and the government as the principal educational and investment policy maker, etc.

Higher Education built on dialogical principles, with curriculums offered through dialogical methods and training students to cultivate their inbuilt dialogical instinct may make graduates more employable. As studies show, among others, the labour industry expects from graduates qualities which presuppose a good training and exploitation of the communion instinct. Such qualities include teamwork skills, communication skills, self-confidence, interactive skills, analytical and problem solving skills, flexibility, computer literacy, etc. (The Gallup Organization, 2010: 25).

Some researches show that dialogical skills are vital both for effective interaction in the workplace and for a good interview performance in the process of looking for employment (Fulgence, 2015: 28-29). This means, dialogue is used as a tool for recruiters to access the employability soft skills of interviewees. It is here, that Martin Buber's philosophy of dialogue is recommended to be mainstreamed in the content, in the method and in the learning outcomes of educational curriculums as a preparation both for seeking employment and for effective delivery in the workplace.

\subsubsection{Dialogue between academia and labour industry}

From the ontological point of view it may be laborious to demonstrate and convince readers that academic endeavours always and everywhere are meant to meet labour needs. However, it is much easier to show how informed professional rendering in the labour industry needs a base and input from the academia. Our interest at this juncture is to show that in the contemporary Tanzanian context the academia on one hand and the labour industry on the other need and depend on each other, and confirm each other's legitimacy.

In the thinking of Martin Buber, two parties of a dialogue are much more united by the common mission they serve (Buber, 1958:45). It is this interdependence, mutual confirmation and common mission which we take as a unifying ground for a dialogical relationship between the two parties (Buber, 2002: 203) [Martin Buber describes a ground of dialogue which expresses a common interest - a unifying force which pulls together the parties of dialogue as 'the sphere of the between]. We take this dialogue to be of different but coordinated forms which if exploited fully may bear fruits needed to sort out the graduates' employability challenges. Such forms of 
dialogue between the academia and the labour industry are as exposed in the following subsections.

\subsubsection{Curriculum development process: needs assessment as a mode} of dialogue

The higher education regulatory organs of Tanzania have a common regulation that the process of establishing a new curriculum or of reviewing an existing curriculum has to involve a thorough needs assessment for the curriculum (NACTE, 2010: vii - viii). This is a dialogical exercise which creates an interactive forum for the academia to be informed by the industry and by the service consumers as regards the relevance and viability of a curriculum in the making or under review. It is an exchange of information which helps expose the nature and magnitude of the knowledge and technology exchanged between the academia offering a curriculum and the industry consuming the products from the academia (Ankrah and Al-Tabbaa, 2015: 388).

A fruitful needs assessment exercise requires genuine mutual openness from both parties. It also needs to be existential in the sense of being homocentric rather than institution centered [this distinction capitalizes on Martin Buber's concept of dialogue as an encounter between subjects as opposed to a confrontation of objects]. The academia has to be sincere in proposing a curriculum which is concretely down-to-earth in relation to the concrete concerns of people as subjects not as objects in the labour market [in the spirit of Martin Buber, the term concreteness is used to rule out abstractness. The same idea features in the Pragmatist approach to education which advocates concrete bearing, practical effectiveness and problemsolving qualities of education as opposed to theoretical, abstract idealistic approach to education]. The process of periodical reviews of existing curriculums as well needs to be genuinely open to criticism in relation to its current and concrete relevance and bearing. Studies show that the labour market is very dynamic in its needs and trends. How can the academia keep itself in pace with such dynamism? This is where the academia is put to task to be always on its toes for it to remain relevant and legitimate.

If we maintain that the labour market is dynamic, we ipso facto agree that the exercise of needs assessment does not guarantee static relevance and bearing of curriculums. This is the reason why the academia has to keep on interacting with the labour market and do the needful to review curriculums accordingly. Curriculums may be reviewed to suit the current needs, but what about graduates who pass through such curriculums, and who carry credentials that bear such ever waning curriculums? Do their knowledge, expertise and skills wane with their respective curriculums? Does this dynamic trend of the labour market make graduate already in employment unemployable? In short, the issue is not only to sort out employability 
challenges of graduates but also to seek means for sustaining employability of those already in employment.

As it is in Tanzania, the majority of first degree academic programmes are run for a minimum of three year. How can Institutions of Higher Learning assure candidates that the programmes which are relevant at the time candidates are admitted for the first time will be relevant at the time they graduate? How can the government which gives loans to students have security of the loans given if it is not sure of the marketability of the curriculums five years to come? Worse still, is it justifiable for the loan beneficiaries to pay back for what is not marketable in the sense that at the time of admission they registered to priority programmes which became obsolete shortly after their graduation?

All these questions provoke an open ended question: is the labour market blindly, haphazardly and irrationally dynamic in its needs and trends or it is deliberately engineered, steered and directed by some rational forces? Does the so called free market entail freedom exclusively of the market itself or rather freedom of the steersmen of the market to guide it the way and to the direction they wish?

\subsubsection{Stakeholders meetings - a forum of dialogue}

This is another dialogical forum which effects interaction between the academia and the labour market. Stakeholders in matters of curriculum development include current and prospective employers, the government as both employer and custodian of academics and labour, schools of the lower levels whose students are prospective candidates to the curriculum, parents and guardians, the community at large, etc. For a more fruitful input these stakeholders are met differently as they offer inputs of different natures and magnitudes. All categories of stakeholders however, share a common feature of entering into a dialogue with the academia. This is confirmed by the study conducted by the Centre for Career Management Skills of the University of Reading - USA in 2008. The study revealed several modalities of interactive engagement between the academia and employers. Among others, these included seeking employers' advice in the curriculum development process, having employers in the classroom either as learners or as teachers, etc (Stanbury, 2008: 4-5, 8, 13, 31). All these are forms of dialogue in which the academia enters into an exchange relationship with the labour industry.

While the stakeholders' category of employers are interested in a curriculum whose graduates have employability skills that guarantee maximum job delivery at the lowest cost possible, the community at large as consumers are interested in the accessibility, quality and affordability of service to be received. The interest of schools, parents, guardians and students is the accessibility, quality of education, affordability, and the marketability of the learning outcomes that the curriculum projects. The role of the 
government as a stakeholder of Higher Education is multifaceted. First, in many countries, taken as a single entity it is the principal employer (Di Matteo, 2015: iii, 1, 4-14). Secondly, it is the principal labour policy maker (McQuaid and Lindsay, 2005: 198; Garrouste and Rodrigues, 2013: 63) and ultimately the Higher Education regulator (Razak and White, 2015: 281) [The Triple Helix Model for Innovation shows a synergic dialogical interaction between universities, industries and the government. In it there sub-models such as the Statist Model, the Laissez-faire Model and the Hybrid Model. In the Statist Model the government plays the role of controlling both the universities and industry. It is in this model the government plays the role of regulating, policy making and legislating for the universities and industries. In the Laissez-faire model each component operates independently only linked by the market. In this model the industry acts as the driving force. It is a model characterized by competition. In the Hybrid model the roles of the three actors intersect and thus collaborate]. Thirdly, it is the biggest proximate beneficiary of taxes earned from labour (Di Matteo, 2013: 12). Over and above, the government is the overall custodian of peoples' welfare the crucial components of which include education and employment.

Such meetings between the academia and stakeholders create room for each party to dialogically air out its views and opinions depending on the nature and motive of each stakeholder. It is a dialogical relationship which establishes some sort of a covenant the breach of which smells betrayal. If the academia produces graduates who do not deliver to the expectations of the stakeholders, in a way, leaves the latter disappointed. If the labour market on the other hand comes with expectations not aired out before, make the unwarranted complaints to the academia. If there are provisions for dialogue and exchange, and yet the Institutions of Higher Learning produce graduates who do not deliver to the preconceived expectations of the market, they are blameworthy.

\subsubsection{Labour industry representation in academic decision making}

The whole academic journey ending with the output of graduates involves a variety of decision making of different natures and levels. We take organs and forums of institutional decision making as a point of interest where dialogue between the academia and the labour industry can be effected. We try to see the possibility of bringing the two parties into a dialogical joint venture on the institutional decision making platforms for a common end of sorting out together the graduates' employability challenges.

In Tanzania it is stipulated and reflected in the Tanzania Universities Act 2005 that the composition of the principal organs of governance of Institutions of Higher Learning (Tanzania Universities Act: 2005: no. 43) [according to the Act the principal organs of governance are the University Council and the University Senate for a university, and the Governing Board 
and the Academic Committee for a University College] should reflect various sectors of the society (Tanzania Universities Act: 2005: no. 44[2])a). Our input in this regard is to make a critical evaluation of the focus, the modality, the magnitude and the concrete role of such societal representation. While the law categorically stipulates of the students representation and gender equality in the composition, the idea of labour market representation remains either not provided for, or presumably covered by the phrase 'various sectors of the society'. This already shows an emphasis gap.

The same gap is concretely seen in some universities' governance structures. With reference to the Charter of The University of Dar es Salaam for instance, we learn that the composition of the Senate of this university does not directly reflect the labour market. A greater percentage of it is from the academic members of staff. The charter explicitly stipulates gender sensitivity in the composition of the Senate but it is silent on the labour market representation. It speaks of a minimal government representation, that is, only two representatives of which however it is not clear whether such representation is of the government as political machinery or as the principal employer of graduates or the owner of the university( University of Dar es Salaam - University Charter, 2007).

Another example from Tanzania is taken from Sokoine University of Agriculture. The compositions of the Council and of the Senate of this university do not explicitly accommodate the labour market representation in such decision making organs (Sokoine University Charter, 2010: art. 13, 20). Saint Augustine University of Tanzania as a non-government university has the same gap in the compositions of its decision making organs. The Charter of this university gives room for only one representative of the Public Service Department who may reflect the labour market (Saint Augustine of Tanzania, Charter, 2010: art. 23, 28).

The same labour market representation gap however, is also found in other universities worldwide. The Senate of The University of York (UK) for instance is composed on the basis of its internal structure, i.e. management, faculties, units and students body with no room for labour market representation. The charter states categorically that the majority of the senate composition should be full time staff (University of York, Charter and Statutes, 2018: art. 12). The composition of its Council does not reflect the labour market representation (University of York, Charter and Statutes, 2018: art. 11). The lack of the labour market representation in the universities' decision making bodies and forums contributes to the failure of universities to produce employable candidates. As a move to enhance employability qualities of graduates we recommend that a dialogical space be created by making the labour market representatives part of the universities' decision making process. 
3.2.2.4. Consultancy as dialogue between academia and labour industry

Consultancy as a professional service is one of the core functions of Institutions of Higher Learning [the core functions of a university are teaching/learning, research and professional service in the form of consultancy]. It may be rendered by an individual expert or by a group of experts. It may be personally organized or organized by a department or by faculty or by the Institution at large. All these modalities create a room and platform for a dialogical exchange and mutual enriching between the professional-academic party on one side and the industry party on the other. This exchange may be in a variety of forms: the industry may come with the business problem to which the academia responds with informed expertise. While the academia offers professional advice, innovation good for the industry, solutions to industrial problems, research inputs, education, etc., the industry on the other side may offer funding, equipment, etc.

Both parties - the industry on one side and the academia on the other thrive if they mutually and dialogically make use of each other. An industry beginning from the blues without prior consultancy has more chances to fail (Lytovchenko, 2016: 35-36). The same applies to an industry without periodical training and reviews carried out by experts from the academia (Lytovchenko, 2016:36). The dialogical role of the academia here is to come with a professional contribution in making and reviewing the industrial business plans, participation in the performance appraisals and audits, etc. It may be a matter of national policy and regulation that the viability of an investment should be backed by an informed business plan prepared or certified by the academia or by some professional bodies. This will eradicate the industry's complaints of lacking a skilled workforce as the industry will have to have a prior consultancy on the availability of the same before embarking on business.

Care must be taken however, that the good intention for a dialogical relationship for mutual benefit may not be changed into a monologue in which one party dictatorially imposes its agenda on the other. An example of this kind of monologue is revealed in the study carried out by Tracy Bailey, Nico Cloete and Pundy Pillay on The Universities and Economic Development in Africa with a focus on the University of Dar es Salaam. Among others, these researchers came out with a finding that some donors welcome consultancies from universities with which they exchange with funding but with their own interests and agenda (Bailey, et al. 69-70). Through consultancy industries will enhance not only their productivity but also their capacities to accommodate and incorporate new expertise carries by the graduate job seekers. Through consultancy also industries will be get skills for training and orienting newly employed graduates in order to equip them with employability skills. 
3.2.2. Research input as a mode of dialogue between academia and industry

Studies show that industries perform better if they welcome innovative researched inputs from academic institutions (Sibiya, 2011: 4). Studies show as well that industrial oriented researches done by academic institutions thrive when their respective research problems are raised by, or come from the industry (Atkinson, 2018: 4) and when at times they are funded by the same (Atkinson, 2018: 4). These are forms of dialogical synergic exchange between industry and academia. While industries help raise and identify problems, the academia through expertise-inspired research and scientific innovations help look for their solutions. While the academia comes with innovative expertise and inventions, the industry on the other hand comes with funding (Sibiya, 2011: 4).

In relation to this paper we investigate to see how graduates' employability challenges taken as an industrial problem can by synergy be sorted out by research inputs from the academia funded by the industry. In relation to the same we maintain that industrial challenges of effective productivity, of human resources development and retention, of coping with advancements of science and technology, of keeping pace with the ever changing demands of the competitive market etc. can effectively and scientifically be sorted out by research inputs from the academia. It is not enough for the academia to prepare graduates for labour without contributing to making the labour market accommodative of, and conducive to the graduates.

3.2.2.6. Labour industry investment in higher education - mode and forum of dialogue

Financial investment in higher education is another mode and forum for dialogue between Labour Industry and the academia. Such investment may be in the form of injection into universities and college funds for research, for quality assurance initiatives, for curriculum development, for academic and professional innovation, for various forms of capital development, for human sources development, for organizing and sponsoring learning events, etc. This gesture gives chance and platform to the Labour Industry to influence and contribute to the job readiness of graduates. Basing on the same gesture employers get a right to claim quality job seekers and a right to question how they portray value for the money invested by the industry. In the spirit of Martin Buber, all this is to be done in the I-Thou attitude in which neither of the parties aims at utilizing or appropriating the other.

Another form of investment through which industries can interact with the academia is to embark on inaugurating and owning institutions of higher learning in the form of Corporate Universities [Apple University was founded 
and owned by the Apple Company in 2008 aiming at preparing executives for the company, to get a scientific way of transmitting the company's legacy, strategies and the corporate culture. Other Corporate Universities inaugurated for the good of their respective companies include Hamburger University - a property of McDonald's founded in 1961; Gas Natural Fenosa University - a property of Gas Natural Fenosa founded as Unione Fenosa University in 2001; Universitas Telefonica - a property of the Telephone Company in Spain founded in 2007]. Industries that own and manage institutions of higher learning have a better chance of developing curriculums which prepare candidates in unison with expectations of such industries (Ilyas, 2017: 85). With the Corporate University Model there exists a dialogical exchange between the respective companies on one hand and the academia and students on the other. While companies offer all forms of resources and facilities, the academia and students in exchange come with expertise and talents - all for the good of the respective companies (Ewer and Russ-Eft, 2017: 36).

However, some studies have shown that an establishment of corporate universities and colleges is a threat to the academic integrity of universities and colleges in particular and to the academia at large. First, academic freedom in such universities is likely to be highly limited or determined by the respective companies (Ewer and Russ-Eft, 2017: 36). Secondly, such corporate universities and colleges are expensive and critically biased in the objectives. This makes enrolment to such universities be corporate-centered rather than student-centered. Again, the learning costs in such universities and college are too high for students from poor families.

In the light of Martin Buber's philosophy of dialogue Corporate Universities are likely to egoistically promote monologue at the expense of dialogue (Cohen, 1983: 153). More chances are there for such Corporate Universities to be loyal and compliant to the visions and missions of the companies that own them at the expense of academic freedom. While capitalizing on the corporate objectives, projected high productivity and high work performance are likely to supersede knowledge and intellectual fulfillment, hence a threat to the integrity of universities and the academia at large. Driven by corporate objectives such universities are egoistically utilitarian as companies use them aiming getting talented candidates, increasing the level of retaining employees and increasing their productivity (Ilyas, 2017: 85).

Here, we pose some questions for further research: do market-need driven curricula accommodate and promote academic freedom or rather determine its boundaries? Are corporate universities and colleges free to gloom their candidates according to the universal standards and trends or they have always to follow the will of the universities' owners and of the prospective employers? What is the repercussion on the academia if the owner of universities and colleges is the same prospective employer of graduates? Is 
it morally in good standing to perceive corporate funds injected into universities as an investment rather than expenditure? [In a corporate spirit which in this paper we take it as utilitarian there has been a shift of perception of taking finances that companies direct to universities not as expenditure but as investment. This may be in the forms of funds for research, corporate human resource development, and other forms of corporate social responsibility extended to universities].

\subsubsection{Dialogue between labour industry and university students}

Another area pertinent to our objective of looking for a common solution to the graduates' employability challenges is the cultivation of a dialogical relationship between the Labour Industry and university students. This is a dialogical relationship cultivated and realized at the time of studies. This dialogical relationship may be in the form of scholarships and sponsorship that students secure from the industry as current or as prospective employers (Soltani-Tafreshi et al. 2008: 2). It may also be in the form of mentorship that professionals from the Labour Industry may offer to university and college students (Stanbury, 2009: 25).

We deem it improper and monological if the two parties keep aloof to each other until the time when the Labour Industry looks for employees and when graduates look for employments. This late mutual need is utilitarian and egoistic in the sense that employers motivated by the market needs look for prospective employees. Graduates on the other hand motivated by the employment need look for jobs. Neither of the two is motivated by the wellbeing or the other. Chances are there that the job seekers' needs are not necessarily the same needs of employers and vice versa. Each party egoistically aims at utilizing the other party for self-interests. In such utilitarian cases job seekers put in the forefront among others, the level and magnitude of remuneration packages, the nature and quality of working conditions, etc. Employers on the other hand capitalize on the employability qualities of the job seekers, their readiness for the job, the way and the magnitude of contribution they will add to the industry's performance.

Utilitarianism and egoism may be sorted out through intersubjective dialogical gestures between the two parties. With the $I$-Thou attitude the two may interact through a variety of ways. First, the Labour Industry may interact with university students by funding their curricular and their extracurricular activities. In return, students may sell images and products of the sponsoring industry through academic exhibitions, sports, tournament, etc.

Another form of dialogical interaction between industry and students is making practical and field training in the industry part of the curriculums and part of the industries' corporate responsibility to the community. This interaction effects an intersubjective dialogue in which parties reciprocate prior knowledge which makes parties know, cherish, appreciate and motivate 
each other for their mutual benefit and flourishing (The Gallup Organization, 2010: 56). An active interaction between the labour industry on one hand and university students on the other makes students know beforehand what the market expects of them. The labour industry on the other hand gets a prior perception of the employees to be in what they have and in what they miss in terms of employability qualities.

\subsection{National philosophy and agenda as medium of dialogue}

In order to succeed realize its goals a nation through its incumbent government puts in place its world view, a general way which guides thinking and acting, the strategies of attaining the goals and the mechanism for monitoring and evaluating itself. In this work, all this is collectively referred to as national philosophy and agenda. Such philosophy and agenda are interpreted and concretized through national policies, national short and long term plans, legislation, national ideologies, etc. Some authors term this national philosophy and agenda as national political context (Noon et al. 2013: 27).

Here, we argue that if both the academia on one hand and employers on the other plan in line with the national philosophy and agenda will jointly address the graduates' employability challenges. If all the curriculums together with their objectives and learning outcomes as prepared by the academia, if all researches and consultancies are guided by the national philosophy and agenda, it will be fair and justifiable such philosophy and agenda to be used a measuring rod for the graduates' employability. From the side of the labour market if all investments are planned and effected in line with the same national philosophy and agenda employers will fairly and justifiably use the same philosophy and agenda to measure the graduates' employability. The national philosophy and agenda in this case, taken as a major determinant of labour trends is used as a medium for dialogical relationship between employers and the academia (Noon et al. 2013: 27).

The Ujamaa philosophy had self-reliance as one of its tenets and principles (Lal, 2010: 1). Tanzania translated this philosophy among others, into education for self-reliance in line with all investments geared towards self-reliance (Kassam, 1994: 2). Policies, national plans for both short and long terms were put in place to concretize self-reliance. With this commonality of philosophy and agenda the academia would be fairly and justifiably culpable if graduates were not contributing to the self-reliance agenda in all circles of life. The labour market on the other hand would not fairly and justifiable be in a position to judge graduates as non employable if demands of such market were not demands of self-reliance as defined by the Ujamaa philosophy. Both the laobur industry and academia have to adhere to the national philosophy and agenda in order to contribute jointly to address the graduates' employability challenges. 


\section{Conclusion}

Complaints and blames from the labour industry exchanged for defensiveness from the academia and Institutions of Higher Learning are neither healthy nor constructive. Each party has a share of responsibility to bear in the current graduates' employability challenges. A lack of proper exchange towards the solution, and a lack of common interest in the process of looking for a sustainable solution is a monologue rather than a dialogue (Buber, 2002: xii-xiv). In the thinking of Martin Buber, a monologue is an I-It relationship, an imposition in which the recipient of such monologue is dehumanized and reduced to an object (Buber, 2002: xii-xiv).

As exposed earlier, for Martin Buber intersubjectivity characterized by a shared ground and a common interest between parties is indispensable for a genuine and fruitful dialogue (Friedman, 1956: 91). The labour industry on one hand and the academia on the other should bear subject faces and interact as subjects looking for a solution for the common interest. In the spirit of intersubjectivity, the two parties have to take the graduates' employability challenges as a problem of both parties. A solution to such challenges as well should be viewed as a common interest.

Intersbujectivity requires all the stakeholders to cultivate transparency of plans and objectives, mutuality, fairness, non-egoistic spirit in missions and visions etc. If all these are seen from the partners' perspective there will be a joint view and unity of mission in preparing and engaging graduates for their own good and for the good of humanity at large.

We recommend a realistic dialogical collaboration between the academia and the labour market in the whole process of preparing university graduates for them to be employable. The concreteness of this collaboration is to be reflected in the exchange of tangible inputs from the industry such as funds, equipment, etc. while the universities in return have to reciprocate intangible inputs of knowledge, innovation, technology, etc. Another form of concrete dialogical collaboration is reciprocating the academic experts and the labour market stakeholders in the decision making organs of the industries and of the universities respectively. With a dialogical attitude, and with a common-interest attitude from all the stakeholders of higher learning and of the labour industry, the problem of unemployability of university graduates will be sorted out.

\section{References}

Ankrah, S. \& Al-Tabbaa, O. (2015). University-Industry Collaboration: A Systematic Review. Scandinavian Journal of Management, 31, 387408. doi: 10.1016/j.scaman.2015.02.003 
Atkinson, R. D. (2018). Industry Funding of University Research: Which States Lead? Information Technology and Innovation Foundation, 5, 1 8.

Cloete, N., Bailey, T., \& Pillay, P. (2011). Universities and economic development in Africa. Dar es Salaam: African Minds.

Buber, M. (1958). I and Thou, 2nd Ed. Translated by Ronald Gregor Smith. Edinburgh: T \& T Clack Ltd.

Buber, M. (2002). Between Man and Man. London: Routledge.

Butler, T. (2006). Anti-Foundational Knowledge Managemen. In Encyclopaedia of Knowledge Management (pp. 1-9), Hershey: Idea Group Reference.

The University of York (2018). Chapter and Statutes, York: The University of York.

Cohen, A. (1983). The Educational Philosophy of Martin Buber. East Brunswick: Associated University Presses Inc.

Di Matteo, L. (2015). An Analysis of Public and Private Sector Employment Trends in Canada: 1990-2013. Toronto: Fraser Institute.

Ewer, G. \& Darlene Russ-Eft (2017). Corporate University Theory and Practice: The Case of Platt University, USA. International Journal of HRD Practice, Policy and Research, 2(1) 35-49.

Flanagan, F. M (2006). The Greatest Educators... Ever! London: Continuum International Publishing Group.

Friedman, M. S. (1956). Martin Buber: The Life o un $f$ Dialogue. Chicago: University of Chicago Press.

Fulgence, K. (2015). Employability of Higher Education Institutions Graduates: Exploring the Influence of Entrepreneurship Education and Employability Skills Development Program Activities in Tanzania, Doctoral Thesis, University of Siegen, Siegen.

Garrouste, C. \& Margarida Rodrigues, (2013). Employability of Young Graduates in Europe. International Journal of Manpower, 53, 62-92.

Green, J. M. (1999). Hope for Our Time: Trends in the Thought of Martin Buber. New York: University of New York Press.

Guilherme, A. \& Morgan, W. J. (2009). Martin Buber's Philosophy of Education and Its Implications for Adult Non-Formal Education. International Journal of Lifelong Education, 57, 565-581. doi: $10.1080 / 02601370903189989$

Ilyas, M. (2017). Making of a Corporate University Model: Transition from Traditional Training to Learning Management System. Journal of Education and Practice, 8(15), 85-90.

Kalufya, N. \& Mwakajinga, L. (2016). Employability of Graduates from Higher Education Institutions in Tanzania. Institute of Social Work Journal, 1(2), 51-68. 
Kassam, Y. (1994). Julius Kambarage Nyerere. Prospects: The Quarterly Review of Comparative Education, 24(1/2), 247-259. doi: 10.1007/ bf02199019

Lal, P. (2010). Militants, Mothers, and the National Family: Ujamaa, Gender and Rural Development in Postcolonial Tanzania. Journal of African History, 51, 1-20.

Lytovchenko, I. (2016). Corporate University as a Form of Employee Training and Development in American Companies. Advanced Education, 5, 35-41. doi: 10.20535/2410-8286.62280

Makulilo, V. B. (2012). Where is Socialism in Tanzania. Elixir International Journal, Social Sciences, 46, 8170-8180. doi: 10.5897/ijpds11.055

Mbalamwezi, J. (2015). Perspectives of Youth on Unemployment in Tanzania: Voices from Dodoma Municipal, Masters Degree Dissertation, Muzumbe University, Morogoro.

Mbise, E. (2016). Managing Students' Job Opportunity Expectations in Tanzanian Context. Business Education Journal, 1(2), 1-17.

Mbwanji, N. H. (2014). The Study of National Skills Development to Facilitate Tanzania to Become a Strong and Competitive Economy by 2025, Dar es Salaam: Author.

McQuaid, R. W. \& Lindsay, C. (2005). The Concept of Employability. Urban Studies, 42(2), 197-219. doi: 10.1080/0042098042000316100

Mjema, G. D. (1999). Youth Unemployment in Tanzania: Nature, Magnitude and Proposal for Possible Solution. University of Dar es Salaam: Economic Research Bureau.

Munishi, E. J. (2016). Factors Contributing to Lack of Employable Skills among Technical and Vocational Education (TVET) Graduates. Business Education Journal, 1 (2), 1-19.

Murphy, D. (1988). Martin Buber's Philosophy of Education. Dublin: Irish Academic Press.

Mwita, K. M., (2018). Tanzania Graduate Employability: Perception of Human Resource Management Practitioners. International Journal of Human Resource Studies, 8, (2), 263-273.

NACTE (2010). Procedures for Curriculum Development and Review, Dares-Salaam: Author.

Ndyali, L. (2016). Higher Education System and Jobless Graduates in Tanzania. Journal of Education and Practice, 7(4), 116-121.

Noon,., Blyton. \& Morrell,. (2013). The Realities of Work: Experiencing Work and Employment in Contemporary Society. New York: Palgrave Macmillan.

Nyerere, J. K., (2018). Ujamaa Essays on Socialism. London: Oxford University Press. 
Rasul,. E. S., Rasul, M., Amnah Abd Rauf, S., Mansor, A. N., Yasin, R. M., \& Mahamod, Z. (2013). Graduate Employability for Manufacturing Industry. Procedia-Social and Behavioral Sciences, 102, 242-250.

Razak, A. A. \& Gareth R. T. White, (2015). The Triple Helix Model for Innovation: A Holistic Exploration of Barriers and Enablers. International Journal of Business and Supply Chain Modelling, 7(3), 278-291.

Seymour, R. (1998). Managing the Jewish Classroom: How to Transform Yourself into a Master Teacher. Los Angeles: Torah Aura Productions.

Shuma, C. J. (2017). Enhancing Employability Skills among Higher Learning Students through Career Guidance and Counseling: Experience from the University of Dodoma and Saint John's University of Tanzania, Dodoma: University of Dodoma.

Sibiya, P. (2011). The Role of Research and Development in Industry and Commerce. International Journal of Scientific and Engineering Research, 2(8), 1-10

Sokoine University of Agriculture (2007). The University Charter. Sokoine: Author.

Soltani-Tafreshi, F., Twigg, D. R. \& Dickens, J. G. (2008). Industrial Sponsorship: Undergraduate Students' Expectations and Achievements. Loughborough: Loughborough University.

Stanbury, D. (2008). Engaging Employers to Enhance Teaching and Learning. Reading: University of Reading.

The Gallup Organization, (2010). Employers' Perception of Graduate Employability: Analytical Report. New York: Author.

The University of Dar es Salaam (2007). The University Charter. Dar es Salaam: Author.

Saint Augustine University of Tanzania (2010). The University Charter. Dar es Salaam: Author.

Yadav, B. ed. (2002). Encyclopedia of Teaching of Education. Delhi:Anmol Publications Pvt., Ltd.

Yona, M. (2008). Popular Histories of Independence and Ujamaa in Tanzania, Doctoral Thesis, University of the Western Cape, Cape Town. 